Note

\title{
LEAF CONSUMPTION BY Diabrotica speciosa (COLEOPTERA: CHRYSOMELIDAE) ADULTS ON DIFFERENT HOST PLANTS
}

\author{
Crébio José Ávila ${ }^{1 *} ;$ José Roberto Postali Parra² \\ ${ }^{1}$ Embrapa Agropecuária Oeste, C.P. 661 - 79804-970 - Dourados, MS - Brasil. \\ ${ }^{2}$ USP/ESALQ - Depto. de Entomologia, Fitopatologia e Zoologia Agrícola, C.P. 09 - 13418-900 - Piracicaba, SP - \\ Brasil. \\ *Corresponding author <crebio@cpao.embrapa.br>
}

\begin{abstract}
Studies related to the feeding behavior of pest insects provide information that will aid the development of control tactics. Leaf consumption by Diabrotica speciosa adults fed on bean, corn, potato and soybean was determined in the laboratory under free-choice (multiple or double-choice) and no-choice (confinement) conditions. In the multiple-choice tests leaf circles were randomly arranged in a circular pattern (arena) inside Petri dishes. The degree of preference for the hosts was determined under double-choice conditions, where common bean was considered the standard host and the remaining plants (soybean, potato and corn) as test hosts. In all trials, two Diabrotica speciosa couples were released and maintained within the dish for 24 hours; the leaf area consumed by the insects was determined after this feeding period. Food type (host) influenced leaf area consumption by $D$. speciosa adults both in free-choice and in no-choice tests $(P<0.05)$. Under freechoice conditions, the insects preferred to feed on bean rather than on soybean, potato or corn, with no differences among these last three host plants $(P>0.05)$. As to the no-choice test, the consumption was higher for corn than for potato, probably to compensate the low nutritional quality of the first host.
\end{abstract}

Key words: insect, root worm, host plant, food preference, food intake

\section{CONSUMO FOLIAR POR ADULTOS DE Diabrotica speciosa (COLEOPTERA: CHRYSOMELIDAE) EM DIFERENTES HOSPEDEIROS}

\begin{abstract}
RESUMO: Estudos relacionados ao comportamento alimentar dos insetos-pragas, podem fornecer informações que auxiliam no desenvolvimento de táticas visando seu controle. Foi determinado, em laboratório, o consumo foliar por adultos de Diabrotica speciosa, quando alimentados com folhas de feijoeiro, milho, batata e soja, sob condições de livre escolha (múltipla e dupla escolha) e sem chance de escolha (confinamento). Nos testes de múltipla escolha, círculos foliares foram dispostos, ao acaso, num arranjo circular (arena) em placas de Petri. O grau de preferência dos hospedeiros foi determinado em condições de dupla escolha, considerandose o feijoeiro a espécie padrão e os demais hospedeiros (soja, batata e milho) como plantas testes. Para todos os testes, dois casais de $D$. speciosa foram liberados no interior da placa e aí mantidos por 24 horas, determinadose, após esse período, a área foliar consumida pelos insetos. O tipo de alimento (hospedeiro) oferecido aos adultos de $D$. speciosa influenciou o grau de consumo foliar tanto nos testes de livre escolha como nos de confinamento $(P<0.05)$. Nos testes de livre escolha, os insetos preferiam se alimentar de folhas de feijoeiro em relação às de batata, soja e milho, sem diferir significativamente entre estas últimas. Em condições de confinamento o consumo foliar é maior em milho do que em batata, provavelmente como compensação pela baixa qualidade nutricional da gramínea em relação às leguminosas.

Palavras-chave: Insecta, vaquinha, planta hospedeira, preferência alimentar
\end{abstract}

\section{INTRODUCTION}

Diabrotica speciosa (Germar, 1824) (Coleoptera: Chrysomelidae) is a species that occurs in several states of Brazil and in a few other countries of South America (Aréstegui, 1976; Krysan, 1986; Bercellini \& Malacalza, 1994). Adults feed on aerial parts of plants, while the larvae, which live underground, consume roots and tubers (Gassen, 1989).
Laboratory studies related to rearing techniques and the bioecology of D. speciosa are documented in the literature (Haji, 1981; Pecchioni, 1988; Silva-Werneck et al., 1995; Milanez \& Parra, 2000; Ávila et al., 2000). However, little research work has been carried out to determine the influence of host plants as food for the adult stage of the species (Ávila \& Parra, 2001; 2002). Reports on to this subject can help to understand the factors that determine the population dynamics of $D$. speciosa in the 
field, providing useful background information for the development of control tactics. The objective of this work was to determine the preference and leaf consumption by adults of Diabrotica speciosa fed with leaves of bean, corn, potato and soybean.

\section{MATERIAL AND METHODS}

The experiments were carried out under controlled conditions of temperature $\left(25 \pm 2^{\circ} \mathrm{C}\right)$, relative humidity $(60 \pm 10 \%)$ and photoperiod (14h photophase). The leaf consumption by adults of $D$. speciosa was evaluated in multiple-choice and confinement (no-choice) tests, where leaf circles of common bean, corn, potato and soybean were utilized. Plants were grown in a shade house and the soil was fertilized according to requirements for each crop. Leaves of the consumption tests were removed from plants at the same physiological age (15 days after emergence). Recently emerged insects from corn-seedling rearings were utilized (Ávila et al., 2000) and maintained for 48 hours feeding on tomato plant leaflets, to eliminate any possibility of occurrence of preimaginal conditioning, since corn would also be utilized in the consumption tests at the adult stage.

In the multiple-choice tests, leaf circles (one for each plant species) were prepared with a $45 \mathrm{~mm}$ diameter hole-puncher and randomly arranged in a circular pattern (arena) inside $15 \mathrm{~cm}$-diameter Petri dishes, with bottoms filled with casting plaster, and covered with moistened filter paper. Two D. speciosa couples were released in the center of the arena and maintained for 24 hours feeding. The remaining leaf area in the circle was determined with an area meter, (CI-203; CID-Incorporated). Consumed leaf area by insects was calculated by difference between the remaining and initial leaf areas. The degree of preference for each host was also determined in double-choice tests, bean plants considered as the standard species and the other hosts (soybean, potato and corn) as test plants.

Two leaf circles from each test plant and two other from bean plants were arranged in an interspersed and equidistant fashion in a circular pattern in the Petri dish. The number of insects per dish, feeding time and the consumed leaf area were performed as in the multiple-choice test. The preference indexes for soybean, potato and corn, relative to bean, were determined by the formula: $\mathrm{C}=2 \mathrm{~A} /(\mathrm{M}+\mathrm{A})$, where $\underline{\mathrm{A}}$ represents the leaf area consumed from the test plant and $\underline{\mathrm{M}}$ the area consumed from the standard plant (Kogan \& Goeden, 1970)

Leaf circles of only one host species were offered to the insects in the confinement consumption tests. The number of individuals utilized per dish, feeding time and the consumed leaf area calculations were performed in a similar way as for the multiple-choice test.
Trials experiments were set up in a completely randomized design, with treatments represented by the four host species, with 20 replicates (Petri dishes) for the multiple- and double-choice trials, and ten replicates for the no-choice trials. Results were submitted to analysis of variance and treatment means were compared by the Tukey test $(P=0.05)$.

\section{RESULTS AND DISCUSSION}

Type of food (host) offered to $D$. speciosa adults influenced leaf consumption both in the multiple-choice and in the no-choice tests $(P<0.05)$. In the multiplechoice test (Figure 1), leaf consumption was higher for bean than for soybean, potato and corn; for these last three hosts, consumption did not differ among themselves. In the double-choice test (Figure 2), leaf consumption was higher for bean (standard plant) than for soybean, corn and potato, similarly what was observed in to the multiple-choice test. All values obtained by the Kogan \& Goeden's (1970) index were below 1 (Figure 3), characterizing the non-preference of the insects for potato, soybean and corn, relatively to bean, since values below 1 indicate consumption preference for the standard plant, while values above 1 indicate preference for the test plant.

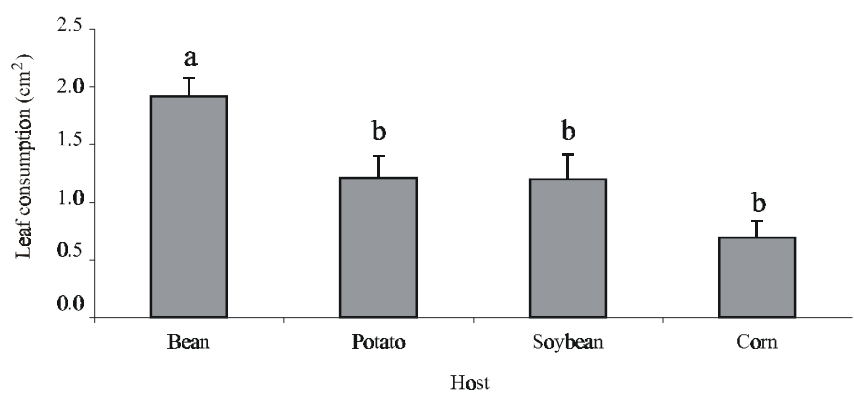

Figure 1 - Leaf area of bean, potato, soybean and corn consumed by Diabrotica speciosa adults, in a multiple-choice test. Temperature: $25 \pm 2{ }^{\circ} \mathrm{C}$; $\mathrm{RH}: 60 \pm 10 \%$, photophase: $14 \mathrm{~h}$. Different letters over the bars indicate distinct values by the Tukey test $(P<0.05)$.

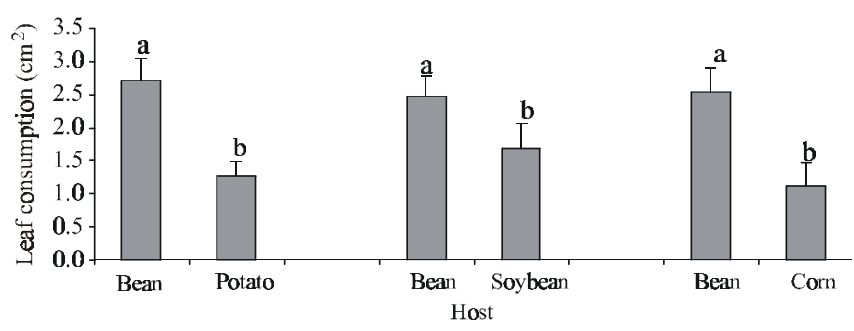

Figure 2 - Leaf area in bean (standard plant), potato, soybean and corn (test plants) consumed by Diabrotica speciosa adults, in a double-choice test. Temperature: $25 \pm 2^{\circ} \mathrm{C}$; RH: $60 \pm 10 \%$, photophase: $14 \mathrm{~h}$. Different letters over the bars indicate distinct values by theTukey test $(P<0.05)$. 
Adults of D. speciosa prefer to feed on bean leaves, instead of soybean and corn leaves. These results explain why adults in this species are frequently found causing greater leaf damage in bean plants under field conditions, even in the presence of other host plants such as soybean and corn in neighboring areas. Teng et al. (1984) also verified that adults of D. balteata, under multiple-choice conditions, preferred to feed on bean instead of potato leaflets.

Under confinement conditions, the consumed leaf area was smaller for potato and greater for corn (Figure 4). The relative increase of corn consumption probably occurred to compensate the low nutritional quality of the leaf tissue in this host. Ávila \& Parra (2002) observed that the ingestion of corn leaves negatively affected the reproduction and survival of $D$. speciosa adults. These authors also verified that the concentration of nitrogen was lower for corn and higher for potato plants; this differential leaf consumption by $D$. speciosa adults could be related to the amounts of nitrogen in the leaves of the tested hosts.

Feeding compensation not always means an advantage for the insect, since it can also increase the ingestion of allelochemicals, compounds that may have deleterious effects on insect development (Simpson \&

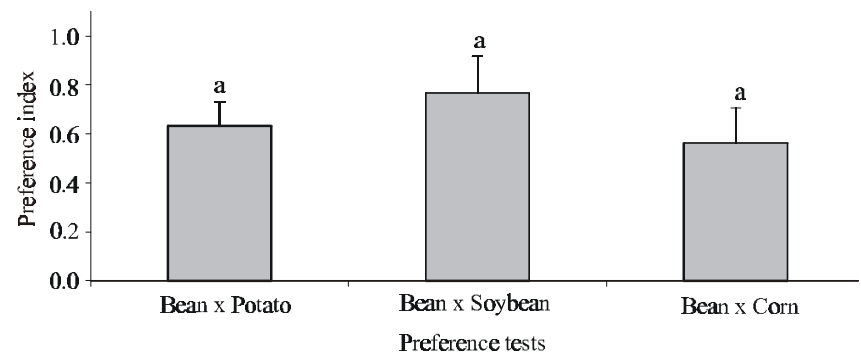

Figure 3 - Preference indices for Diabrotica speciosa adults, in a double-choice test, for each test plant (potato, soybean and corn) relatively to the standard plant (bean). Temperature: $25 \pm 2^{\circ} \mathrm{C}$; RH: $60 \pm 10 \%$, photophase: $14 \mathrm{~h}$. Different letters over the bars indicate distinct values by the Tukey test $(P<0.05)$.

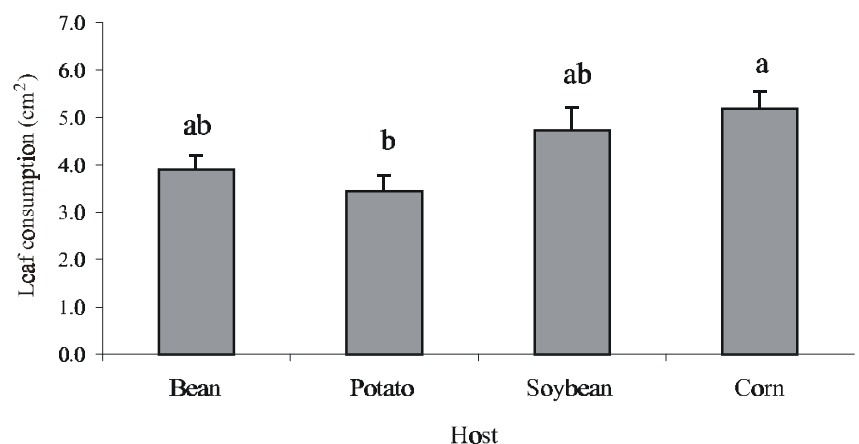

Figure 4 - Leaf area of bean, potato, soybean and corn consumed by Diabrotica speciosa adults, in a no-choice test. Temperature: $25 \pm 2^{\circ} \mathrm{C}$; RH: $60 \pm 10 \%$, photophase: $14 \mathrm{~h}$. Different letters over the bars indicate distinct values by the Tukey test $(P<0.05)$.
Simpson, 1990). The egg-laying capacity in insects is determined by oogenesis, a biological process influenced by the availability of nutrients present in the female's body (Wheeler, 1996). However, other biochemical and/or morphological plant factors could influence consumption by the insects (Norris \& Kogan, 1980); such parameters were not determined in this research.

Studies on the feeding behavior of $D$. speciosa larvae and adults on host plants, as well as the effects of food on their development might help understanding factors which determine the population dynamics of this pest in the field. This kind of information, when properly interpreted, can help to develop control strategies that are based, for example, on host alternation or sequences to be adopted in the planting systems, depending on different degrees of plant susceptibility and/or nutritional quality for pest development and survival (Levine \& OloumiSadeghi, 1991; Panizzi \& Parra, 1991). Ávila (1999) demonstrated that the type of host plant available in the cropping area has a strong influence on $D$. speciosa survival and reproduction, when reported that corn and bean grown in association were more favorable for $D$. speciosa multiplication than corn as a monocrop, since the bean plant is a suitable food for adults while corn is suitable for the larvae.

\section{REFERENCES}

ARÉSTEGUI, A.P. Plagas de la papa en Andahuaylas-Apurimac. Revista Peruana de Entomologia, v.19, p.97-98, 1976.

ÁVILA, C.J. Técnica de criação e influência do hospedeiro e da temperatura no desenvolvimento de Diabrotica speciosa (Germar, 1824) Coleoptera: Chrysomelidae). Piracicaba: USP/ESALQ, 1999. 102p. (Tese Doutorado)

ÁVILA, C.J.; PARRA, J.R.P. Influência da idade do feijoeiro sobre o consumo foliar e fecundidade de Diabrotica speciosa. Revista de Agricultura, v.76, p.299-306, 2001.

ÁVILA, C.J.; PARRA, J.R.P. Desenvolvimento de Diabrotica speciosa (Germar) (Coleoptera: Chrysomelidae) em diferentes hospedeiros. Revista Ciência Rural, v.32, p.739-743, 2002.

ÁVILA, C.J.; TABAI, A.C.P.; PARRA, J.R.P. Comparação de técnicas para criação de Diabrotica speciosa (Germar) (Coleoptera: Chrysomelidae) em dietas natural e artificial. Anais da Sociedade Entomológica do Brasil, v.29, p.257-267, 2000.

BERCELLINI, N.; MALACALZA, L. Plagas y depredadores en soja en el noroeste de la provincia de Buenos Aires (Arg.) Turrialba, v.44, p.244254, 1994.

GASSEN, D.N. Insetos subterrâneos prejudiciais às culturas no sul do Brasil. Passo Fundo: EMBRAPA, CNPT, 1989. 49p.

HAJI, N.F.P. Biologia, dano e controle do adulto de Diabrotica speciosa (Germar, 1824) (Coleoptera: Chrysomelidae) na cultura da batatinha (Solanum tuberosum L.). Piracicaba: USP/ESALQ, 1981. 53p. (Tese Doutorado)

KOGAN, M.; GOEDEN, R.D. The host-plant range of Lema trilineata daturaphila (Coleoptera: Chrysomelidae). Annals of the Entomological Society of America, v.63, p.1175-1180, 1970.

KRYSAN, J.L. Introduction: biology, distribution, and identification of pest Diabrotica. In: KRYSAN, J.L.; MILLER, T.A. (Ed.) Methods for study of the pest Diabrotica. New York: Springer Verlag, 1986. cap.1, p.123.

LEVINE, E.; OLOUMI-SADEGHI, H. Management of diabroticite rootworm in corn. Annual Review of Entomology, v.36, p.229-255, 1991. 
MILANEZ, J.M.; PARRA, J.R.P. Biologia e exigências térmicas de Diabrotica speciosa (Germar) (Coleoptera: Chrysomelidae) em laboratório. Anais da Sociedade Entomológica do Brasil, v.29, p.23$29,2000$.

NORRIS, D.M.; KOGAN, M. Biochemical and morphological bases of resistance. In: MAXWELL, F.G.; JENNINGS, P.R. (Ed.) Breeding plants resistant to insects. Chichester: John Wiley, 1980. p.23-61.

PANIZZI, A.R.; PARRA, J.R.P. A ecologia nutricional e o manejo integrado de pragas. In: PANIZZI, A.R.; PARRA, J.R.P. (Ed.) Ecologia nutricional de insetos e suas implicações no manejo de pragas. Piracicaba: Manole, 1991. p.313-336.

PECCHIONI, M.T.D. Crianza de Diabrotica speciosa (Coleoptera: Chrysomelidae) bajo condiciones de laboratorio. Revista Peruana de Entomologia, v.31, p.86-90, 1988.

SILVA-WERNECK, J.O.; DE FARIA, M.R.; ABREU NETO, J.R.M.V.; MAGALHÃES, B.P.; SCHIMIDT, F.G.V. Técnica de criação de Diabrotica speciosa (Germ.) (Coleoptera: Chrysomelidae) para bioensaios com bacilos e fungos entomopatogênicos. Anais da Sociedade Entomológica do Brasil, v.24, p.45-52, 1995.
SIMPSON, S.L.; SIMPSON, C.L. Mechanisms of compensation by phytophagous insects. In: BERNAYS, E.A. (Ed.) Focus on insect-plant interactions. Boca Raton: CRC Press, 1990. v.2, p.111-160.

TENG, H.J.; WADDILL, V.; SLANSKY, F.; STRAYER, J. Performance and host preference of adult banded cucumber beetles, Diabrotica balteata when offered several crops. Journal of Agricultural Entomology, v.1, p.330-338, 1984.

WHEELER, D. The role of nourishment in oogenesis. Annual Review of Entomology, v.41, p.407-431, 1996.

Received October 19, 2002

Accepted July 21, 2003 